Research Article

\title{
Comparative evaluation of amisulpride and escitalopram on Hamilton anxiety rating scale among depression patients in a tertiary care teaching hospital in Nepal
}

\author{
Vijay Kaul ${ }^{1}$, Shakti B. Dutta ${ }^{2}$, Mirza A. Beg", Shalu Bawa ${ }^{2}$, Mohammed Anjoom ${ }^{2}$, \\ Nand K. Singh ${ }^{3}$, Srihari Dutta ${ }^{4}$
}

\begin{abstract}
${ }^{1}$ Department of Psychiatry, Nepalganj Medical

College, Nepalganj, Nepal, ${ }^{2}$ Department of Pharmacology, Shri Guru Ram Rai Institute of Medical \& Health Sciences, Dehradun, Uttarakhand, India, ${ }^{3}$ Department of Psychiatry, Shri Guru Ram Rai Institute of Medical \& Health Sciences, Dehradun, Uttarakhand, India, ${ }^{4}$ Immunization Health Specialist, UNICEF, India Country Office, New Delhi, India
\end{abstract}

Received: 19 February 2015 Accepted: 07 March 2015

*Correspondence to:

Dr. Mirza A. Beg, Email: mabeg1997@gmail. com

Copyright: (C) the author(s), publisher and licensee Medip Academy. This is an openaccess article distributed under the terms of the Creative Commons Attribution NonCommercial License, which permits unrestricted noncommercial use, distribution, and reproduction in any medium, provided the original work is properly cited.

\begin{abstract}
Background: Depression is an important global public health problem and is a major cause of disability and premature death. The present study was conducted to compare efficacy and safety of amisulpride and escitalopram on Hamilton anxiety rating scale (HAM-A) among depression patients in a tertiary care teaching hospital in Nepal. Methods: The study was conducted in patients for 1-year in the Department of Neuropsychiatry, Nepalgunj Medical College and Teaching Hospital. A total of 117 depression patients were divided into two groups. Group I (58 patients) received amisulpride tablet at a dose of $50 \mathrm{mg} /$ day and Group II (59 patients) were given escitalopram at a dose of $10 \mathrm{mg} /$ day. The patients were required to follow-up at 4,8 and 15 weeks. The efficacy of the drugs was calculated by HAM-A. Adverse drug reactions (ADRs) were monitored at every follow-up. Appropriate statistical tools using Graphpad instat 3.0 were used for analysis $p<0.05$ was considered significant. Results: HAM-A score in group receiving amisulpride at 0 and 15 weeks was $19.83 \pm 0.33$ and $8.17 \pm 0.32(\mathrm{p}<0.0001)$. HAM-A score in group receiving escitalopram at 0 and 15 weeks was $20.76 \pm 0.28$ and $8.98 \pm 0.24(\mathrm{p}<0.0001)$. Gastrointestinal disturbances, sexual disturbances, amenorrhea, lactation, agitation, and insomnia were the commonly encountered ADRs.

Conclusion: Both amisulpride and escitalopram were highly effective in the treatment of anxiety in depression patients during the study period. Further, more clinical studies with longer follow-up duration are needed to substantiate the therapeutic effects of amisulpride.
\end{abstract}

Keywords: Depression, Amisulpride, Escitalopram, Hamilton anxiety rating scale

\section{INTRODUCTION}

Depression is an important global public health problem and is a major cause of disability and premature death. ${ }^{1}$ It can be defined as a mental state, which is characterized by feelings of sadness, loneliness, despair, low self-esteem, and self-reproach. ${ }^{2}$ The report on global burden of disease estimates the point prevalence of unipolar depressive episodes to be $1.9 \%$ for men and $3.2 \%$ for women, and the 1-year prevalence has been estimated to be $5.8 \%$ for men and $9.5 \%$ for women. It is estimated that by the year 2020 , if current trends for demographic and epidemiological 
transition continue, the burden of depression will increase to $5.7 \%$ of the total burden of disease and it would be the second leading cause of disability-adjusted life years, second only to ischemic heart disease. ${ }^{3}$

Depression is characterized by a typically chronic course with associated anxiety symptoms as co-morbidity. ${ }^{4,5}$ Associated anxiety symptoms may result in greater symptom severity, higher suicidal risk, and poor treatment response than either depression or anxiety alone. ${ }^{6}$ A significant overlap exists in the pathophysiologic components of depression and anxiety involving serotonergic, noradrenergic, and GABAergic systems in brain and their treatment. ${ }^{7}$ Escitalopram, the $\mathrm{S}$-enantiomer of racemic citalopram, is a selective serotonin reuptake inhibitor that has an additional modulatory effect at an allosteric binding site on the serotonin transporter protein. ${ }^{8}$ Escitalopram has been demonstrated in many placebo-controlled, randomized trials to be an efficacious antidepressant for major depressive disorders (MDD)., ${ }^{9,10}$ Amisulpride is a substituted benzamide derivative structurally related to sulpiride. It belongs to the secondgeneration antipsychotic that preferably binds to dopamine D2/D3 receptors in limbic rather than striatal structures. ${ }^{11}$ It has been proposed that antagonism at 5-HT2A receptors and/ or partial agonism at 5-HT1A receptors may play a role in the antianxiety effect of atypical antipsychotics. ${ }^{12,13}$ Studies of atypical antipsychotics in other disease states, such as bipolar disorder, have shown positive results for overall anxiety scores, but these trials did not look specifically at generalized anxiety disorder (GAD), and anxiety was a secondary outcome. ${ }^{14,15}$ Amisulpride is indicated for the treatment of acute and chronic schizophrenia with prominent positive and/ or negative symptoms. Its effectiveness in the improvement of both the positive and negative symptoms is related to a dose-dependent blockade of dopamine receptors. ${ }^{16}$ The presumed selectivity of amisulpride for D2 and D3 dopamine receptors has led to the prevailing hypothesis that modulation of dopaminergic signaling is responsible for its antidepressant efficacy. Based on the above observations, the present study was conducted to compare efficacy and safety of amisulpride and escitalopram on Hamilton anxiety rating scale (HAM-A) among depression patients in a tertiary care teaching hospital in Nepal.

\section{METHODS}

This study was conducted in the Department of Neuropsychiatry, Nepalgunj Medical College and Teaching Hospital, Nepalgunj, for a period of 1-year from the month of January 2013 to December 2013.

Inclusion criteria: (a) All drug-naive patients attending the neuropsychiatry outpatient department, of both sexes who were diagnosed as F 34.1, according to ICD 10, (World Health Organization, 2008), (b) Score $\geq 14$ points on the HAM-A (1980) on the first screening visit. Exclusion criteria: (a) Use of psychoactive substances, (b) any systemic illness, (c) lactating and pregnant women, (d) known case of psychiatric illness as described by ICD 10, (World Health Organization, 2008), (e) history of drug reaction. The study was conducted after approval from Institutional Ethics Board. Written informed consent was obtained from all the patients/legal guardians.

\section{Study design}

The study was an open-label study conducted from January 2013 to December 2013. A total of 117 patients diagnosed with depression were randomly divided into two groups: group I (58 patients) received amisulpride tablet at a dose of $50 \mathrm{mg}$ /day and Group II (59 patients) were given escitalopram at a dose of $10 \mathrm{mg} /$ day. Drug compliance was monitored rigorously, but no drug blood levels were monitored due to lack of any such facility locally. The patients were required to follow-up at 4, 8 and at the end of study period at 15 weeks. Adverse drug reactions (ADRs) were monitored at every follow-up. Appropriate statistical tools using Graphpad instat 3.0 were used for analysis. $\mathrm{p}<0.05$ was considered significant.

\section{RESULTS}

Of a total of 117 patients who were included in the study, 18 patients dropped out from the study due to varying reasons: Totally, 6 patients were lost to follow-up, 6 patients were lost due to ADRs, 3 patients were lost due to lack of cost effectiveness, 2 patients requested therapy change and 1 patient was uncooperative. Overall, 99 patients completed the study: Totally, 58 patients in amisulpride group and 59 patients in escitalopram group. The mean age of the patients in the study drug groups was $46.84 \pm 1.10$ years. The male:female \% age was $41(41.41 \%)$ and $58(58.59 \%)$. According to the residence, $31(31.31 \%)$ patients were residing in urban areas, and $52(52.53 \%)$ patients were residing in rural areas. A total of $47(47.47 \%)$ patients were illiterate, and $52(52.53 \%)$ patients were literate. According to occupation, $65(65.66 \%)$ patients were farmers, $23(23.23 \%)$ patients were employed and $11(11.11 \%)$ belonged to others category (Tables 1 and 2).

The efficacy of the drugs was calculated by HAM-A. All values were expressed in mean \pm standard error mean. At the beginning of the study, the score in amisulpride group according to HAM-A was $19.83 \pm 0.33$ and in the escitalopram group was $20.76 \pm 0.28$. Patients were followed up at 4 weeks, 8 weeks and at 15 weeks. Progressive improvement was seen in both the groups over the study period (Table 3). At the end of the study, the HAM-A score in amisulpride group was $8.17 \pm 0.32$ and in the escitalopram group was $8.98 \pm 0.24$. Intragroup comparison was done between baseline and 15 weeks, and highly significant improvement was seen in both groups $(\mathrm{p}<0.0001)$ (Table 3 ). At the end of the study (15 weeks), intergroup comparison was done between the amisulpride and escitalopram group, 
Table 1: Demographic profile of study group.

\begin{tabular}{|lc|}
\hline Variables & Total (\%) \\
\hline Age (mean) & $46.84 \pm 1.10$ \\
\hline Sex (M:F) & $41(41.41): 58(58.59)$ \\
\hline Residence (urban:rural) & $31: 68(31.31: 68.69)$ \\
\hline Education & $47(47.47)$ \\
\hline Illiterate & $52(52.53)$ \\
\hline Literate & \\
\hline Occupation & $65(65.66)$ \\
\hline Farming & $23(23.23)$ \\
\hline Employed & $11(11.11)$ \\
\hline Others & \\
\hline
\end{tabular}

All the values are expressed in mean \pm standard error mean

Table 2: Dropouts.

\begin{tabular}{|lccc|}
\hline Variables & $\begin{array}{c}\text { Amisulpride } \\
\mathbf{n = 5 8}\end{array}$ & $\begin{array}{c}\text { Escitalopram } \\
\mathbf{n = 5 9}\end{array}$ & $\begin{array}{c}\text { Total } \\
\mathbf{n = 9 9}\end{array}$ \\
\hline Total drop outs & 10 & 8 & 18 \\
\hline Reasons & & & \\
\hline Lost to follow-up & 3 & 3 & 6 \\
\hline Un cooperative & 0 & 1 & 1 \\
\hline ADR & 3 & 3 & 6 \\
\hline $\begin{array}{l}\text { Requested } \\
\text { therapy change }\end{array}$ & 1 & 1 & 2 \\
\hline $\begin{array}{l}\text { Lack of cost } \\
\text { effectiveness }\end{array}$ & 3 & 0 & 3 \\
\hline $\begin{array}{l}\text { Total completed } \\
\text { study }\end{array}$ & 48 & 51 & 99 \\
\hline
\end{tabular}

ADR: Adverse drug reaction

which was not significant ( $p>0.05$ ). A total of 44 ADRs were seen during the study period. 25 ADRs were seen in patients in amisulpride group, and 19 ADRs were seen in escitalopram group. Gastrointestinal disturbances were seen in 5 patients in amisulpride group and 9 patients in escitalopram group followed by delayed orgasm in 5 patients in amisulpride group and 2 patients in escitalopram group, amenorrhoea in 4 patients in amisulpride group, dryness of mouth in 3 patients in amisulpride group and 2 patients in escitalopram group, erectile dysfunction in 2 patients in amisulpride group and 1 patient in escitalopram group, agitation in 2 patients in both groups, giddiness, insomnia and weight gain in 1 patient in each group and lactation in 1 patient in amisulpride group (Table 4).

\section{DISCUSSION}

Depressive disorders lead to significant dysfunction, disability and poor quality of life in sufferers and pose a significant burden on the caregivers. ${ }^{17,18}$ In the present study, there was a higher prevalence of depression in females which was in accordance with previous studies by Sethi and Prakash; Ramachandran et al., depicting that women
Table 3: Efficacy as per HAM-A.

\begin{tabular}{|lccc|}
\hline Drug & At beginning & At the end & p value \\
\hline Amisulpride & $19.83 \pm 0.33$ & $8.17 \pm 0.32$ & $<0.0001$ \\
\hline Escitalopram & $20.76 \pm 0.28$ & $8.98 \pm 0.24$ & $<0.0001$ \\
\hline
\end{tabular}

All the values are expressed in mean \pm standard error mean, HAM-A: Hamilton anxiety rating scale

Table 4: ADRs.

\begin{tabular}{|lcc|}
\hline Variables & $\begin{array}{c}\text { Amisulpride } \\
\mathbf{n = 4 8}\end{array}$ & $\begin{array}{c}\text { Escitalopram } \\
\mathbf{n = 5 1}\end{array}$ \\
\hline $\begin{array}{l}\text { Total patients with } \\
\text { ADR }\end{array}$ & $25(59 \%)$ & $19(42.2 \%)$ \\
\hline $\begin{array}{l}\text { Gastrointestinal } \\
\text { disturbances }\end{array}$ & 5 & 9 \\
\hline Delayed orgasm & 5 & 2 \\
\hline Amenorrhea & 4 & 0 \\
\hline Dryness of mouth & 3 & 2 \\
\hline Erectile dysfunction & 2 & 1 \\
\hline Agitation & 2 & 2 \\
\hline Giddiness & 1 & 1 \\
\hline Insomnia & 1 & 1 \\
\hline Weight gain & 1 & 0 \\
\hline Lactation & 1 & 1 \\
\hline ADR: Advers & & \\
\hline
\end{tabular}

ADRs: Adverse drug reactions

were more commonly suffering from depression. ${ }^{19,20}$ The greater prevalence of depression among women is not fully understood, although potential contributors include different responses to stressful life events, genetic predisposition and hormonal differences. ${ }^{21}$ The mean age group in our study was $46.84 \pm 1.1$ years which were comparable with previous studies by Dutta et al. and Grover et al. where incidence of depression was seen in more commonly in 30-51 years age group. ${ }^{22,23}$ More depression patients were seen in rural areas as compared to urban areas in the present study. This was comparable with previous studies by Giel and Harding; Gautam and Kapur where rural background subjects were found to be somatising more than the urban subjects. ${ }^{24,25}$ In our study, more number of literates were suffering from depression which was comparable with previous study by Barsky, ${ }^{26}$ Farmers were the major sufferers of depression, which was in accordance with previous studies by Roberts and $\mathrm{Lee}^{27}$ which, based on data from the Epidemiologic Catchment Area program, found "farming, fishing, and forestry" to have the highest lifetime risk for major depression.

A comparative evaluation of escitalopram and amisulpride was done in depression patients over HAM-A in this 15 weeks study. The study results indicate that both escitalopram and amisulpride were beneficial in reducing anxiety symptoms in depression patients. There was highly significant improvement have been observed in HAM-A in both the groups over the study period. Intragroup comparison 
was made between baseline and 15 weeks, highly significant improvement was observed in both the groups $(\mathrm{p}<0.0001)$. At the end of the study (15 weeks), intergroup comparison was done between the group, no significant difference have been observed $(p>0.05)$. It indicates that escitalopram and amisulpride are equally efficacious in improving the HAM-A and reducing anxiety symptoms in depression patients. Our result findings were in concurrence with a randomized, double-blind placebo-controlled, multicenteric, trial in adult subjects of GAD by Bose et al., where escitalopram was compared with venlafaxine extended release. ${ }^{28}$ Also, Soares et al. compared the efficacy and safety of desvenlafaxine and escitalopram in MDD with symptoms of anxiety in postmenopausal women and escitalopram was highly effective. ${ }^{29}$ Amisulpride, a selective D2/D3 receptor second generation antipsychotic is indicated for the treatment of acute and chronic schizophrenia. ${ }^{16}$ In the present study, the antianxiety effect of amisulpride was compared at baseline and at 15 weeks in depressive patients, and highly significant improvement was seen $(\mathrm{p}<0.0001)$. Previous studies with other atypical antipsychotics like ariprazole, olanzapine, risperidone and quetiapine have shown similar results in improving HAM-A. ${ }^{30-33}$

The unique therapeutic profile of amisulpride has proven difficult to explain in light of its known pharmacological profile. There is some evidence that amisulpride has some selectivity for presynaptic dopamine autoreceptors and exhibits limbic versus striatal selectivity, particularly at low doses, and it has been suggested that this might account for its therapeutic profile. ${ }^{34}$

Safety analysis was done for both the groups and ADRs were assessed at each follow-up. Gastrointestinal disturbances were seen most commonly with both the groups and have been proven in earlier studies. ${ }^{35,36}$ Endocrinological effects like amenorrhea and lactation were seen in amisulpride group and have been seen in previous studies. ${ }^{37}$ Other side effects such as insomnia, agitation and dryness of mouth were seen similarly in both groups and were comparable with previous studies. . $^{35,36}$

\section{Study limitations}

The study was an open-label study. Both doctors and patients were aware of the treatments. Hence, there could be chances of biasing. Also, the patients were followed up for only 15 weeks. A longer duration of follow-up could have yielded different results.

\section{CONCLUSION}

Both escitalopram and amisulpride were highly effective in depression patients in improving HAM-A during the study period. Further, more clinical studies with longer follow-up duration are needed to substantiate the beneficial effects of amisulpride.

\section{AKNOWLEDGMENTS}

Authors are thankful to the dean and medical superintendent of the Nepalganj Medical College, Nepalganj, Nepal, for their kind support in conducting the study.

\section{Funding: No funding sources}

Conflict of interest: None declared

Ethical approval: The study was approved by the Institutional Ethics Committee

\section{REFERENCES}

1. Akiskal HS. Mood disorders: historical introduction and conceptualoverview. In:Kaplan and Sadock's Comprehensive Textbook of Psychiatry. $8^{\text {th }}$ Edition. Philadelphia: Lippincott Williams \& Wilkins; 2005: 1559-75.

2. Ray S, Chogtu B. Prescribing trends in depression: a drug utilization study done at a tertiary healthcare centre. J Clin Diagn Res. 2011;5(3):573-7.

3. Lopez AD, Mathers CD, Ezzati M, Jamison DT, Murray CJ. Global Burden of Disease and Risk Factors. Washington: The World Bank; 2006.

4. Belzer K, Schneier FR. Comorbidity of anxiety and depressive disorders: issues in conceptualization, assessment, and treatment. J Psychiatr Pract. 2004;10(5):296-306.

5. Kessler RC, Nelson CB, McGonagle KA, Liu J, Swartz M, Blazer DG. Comorbidity of DSM-III-R major depressive disorder in the general population: results from the US National Comorbidity Survey. Br J Psychiatry Suppl. 1996;17-30.

6. Baldwin DS, Lopes AT. The influence of comorbid anxiety disorders on outcome in major depressive disorder. Medicographia. 2009;31:126-31.

7. Keller MB, Krystal JH, Hen R, Neumeister A, Simon NM. Untangling depression and anxiety: clinical challenges. J Clin Psychiatry. 2005;66(11):1477-84.

8. Sánchez C. The pharmacology of citalopram enantiomers: the antagonism by R-citalopram on the effect of S-citalopram. Basic Clin Pharmacol Toxicol. 2006;99(2):91-5.

9. Thase ME. Managing depressive and anxiety disorders with escitalopram. Expert Opin Pharmacother. 2006;7(4):429-40.

10. Waugh J, Goa KL. Escitalopram: a review of its use in the management of major depressive and anxiety disorders. CNS Drugs. 2003;17(5):343-62.

11. McKeage K, Plosker GL. Amisulpride: a review of its use in the management of schizophrenia. CNS Drugs. 2004;18(13):933-56

12. Carson WH, Kitagawa H. Drug development for anxiety disorders: new roles for atypical antipsychotics. Psychopharmacol Bull. 2004;38(1):38-45.

13. Overstreet DH, Knapp DJ, Moy SS, Breese GR. A 5-HT1A agonist and a 5-HT2c antagonist reduce social interaction deficit induced by multiple ethanol withdrawals in rats. Psychopharmacology (Berl). 2003;167(4):344-52.

14. Tohen M, Vieta E, Calabrese J, Ketter TA, Sachs G, Bowden $\mathrm{C}$, et al. Efficacy of olanzapine and olanzapinefluoxetine combination in the treatment of bipolar I depression. Arch Gen Psychiatry. 2003;60(11):1079-88.

15. Hirschfeld RM, Weisler RH, Raines SR, Macfadden W, BOLDER Study Group. Quetiapine in the treatment of anxiety in patients with bipolar I or II depression: a secondary 
analysis from a randomized, double-blind, placebocontrolled study. J Clin Psychiatry. 2006;67(3):355-62.

16. Scatton B, Claustre Y, Cudennec A, Oblin A, Perrault G, Sanger DJ, et al. Amisulpride: from animal pharmacology to therapeutic action. Int Clin Psychopharmacol. 1997;12 Suppl 2:S29-36.

17. Chadda RK. Social support and psychosocial dysfunction in depression. Indian J Psychiatry. 1995;37(3):119-23.

18. Chaudhury PK, Deka K, Chetia D. Disability associated with mental disorders. Indian J Psychiatry. 2006;48(2):95-101.

19. Sethi BB, Prakash R. Depression in industrial population. An overview of Indian research in depression. Indian $\mathrm{J}$ Psychiatry. 1979;21:359-61.

20. Ramachandran V, Menon MS, Arunagiri S. Socio-cultural factors in late onset depression. Indian $\mathrm{J}$ Psychiatry. 1982;24(3):268-73.

21. National Institute of Mental Health. Women and Depression, Discovering Hope. Bethesda, MD: US Department of Health and Human Services, National Institute of Health, National Institute of Mental Health; 2009.

22. Dutta SB, Beg MA, Sindhu S, Singh NK. Role of pharmacoepidemiology in psychopharmacology: a study in psychiatric out-patient department of a tertiary care teaching hospital at Dehradun, Uttarakhand. Int J Basic Clin Pharmacol. 2014;3(4):637-43.

23. Grover S, Avasth A, Kalita K, Dalal PK, Rao GP, Chadda RK, et al. IPS multicentric study: antidepressant prescription patterns. Indian J Psychiatry. 2013;55(1):41-5.

24. Giel R, Harding TW. Psychiatric priorities in developing countries. Br J Psychiatry. 1976;128:513-22.

25. Gautam SK, Kapur RL. Psychiatric patients with somatic complaints. Indian J Psychiatry. 1977;19:75-80.

26. Barsky AJ. Amplification, somatisation and the somatoform disorders. Psychosomatics. 1992;33:28-34.

27. Roberts RE, Lee ES. Occupation and the prevalence of major depression, alcohol, and drug abuse in the United States. Environ Res. 1993;61(2):266-78.

28. Bose A, Korotzer A, Gommoll C, Li D. Randomized placebo-controlled trial of escitalopram and venlafaxine XR in the treatment of generalized anxiety disorder. Depress Anxiety. 2008;25(10):854-61.

29. Soares CN, Thase ME, Clayton A, Guico-Pabia CJ, Focht K, Jiang Q, et al. Desvenlafaxine and escitalopram for the treatment of postmenopausal women with major depressive disorder. Menopause. 2010;17(4):700-11.

30. Hoge EA, Worthington JJ $3^{\text {rd }}$, Kaufman RE, Delong HR, Pollack MH, Simon NM. Aripiprazole as augmentation treatment of refractory generalized anxiety disorder and panic disorder. CNS Spectr. 2008;13(6):522-7.

31. Pollack MH, Simon NM, Zalta AK, Worthington JJ, Hoge EA, Mick E, et al. Olanzapine augmentation of fluoxetine for refractory generalized anxiety disorder: a placebo controlled study. Biol Psychiatry. 2006;59(3):211-5.

32. McIntyre A, Gendron A, McIntyre A. Quetiapine adjunct to selective serotonin reuptake inhibitors or venlafaxine in patients with major depression, comorbid anxiety, and residual depressive symptoms: a randomized, placebocontrolled pilot study. Depress Anxiety. 2007;24(7):487-94.

33. Simon NM, Hoge EA, Fischmann D, Worthington JJ, Christian KM, Kinrys G, et al. An open-label trial of risperidone augmentation for refractory anxiety disorders. J Clin Psychiatry. 2006;67(3):381-5.

34. Schoemaker H, Claustre Y, Fage D, Rouquier L, Chergui K, Curet $\mathrm{O}$, et al. Neurochemical characteristics of amisulpride, an atypical dopamine D2/D3 receptor antagonist with both presynaptic and limbic selectivity. J Pharmacol Exp Ther. 1997;280(1):83-97.

35. Rosenzweig P, Canal M, Patat A, Bergougnan L, Zieleniuk I, Bianchetti G. A review of the pharmacokinetics, tolerability and pharmacodynamics of amisulpride in healthy volunteers. Hum Psychopharmacol. 2002;17(1):1-13.

36. Gartlehner G, Gaynes BN, Hansen RA, Thieda P, DeVeaughGeiss A, Krebs EE, et al. Comparative benefits and harms of second-generation antidepressants: background paper for the American College of Physicians. Ann Intern Med. 2008;149(10):734-50.

37. Chabra V, Bhatia MS. Amisulpride: a brief review. Delhi Psychiatry J. 2007;10(2):140-3.

doi: $10.5455 / 2319-2003 . i j b c p 20150438$

Cite this article as: Kaul V, Dutta SB, Beg MA, Bawa S, Anjoom M, Singh NK, Dutta S. Comparative evaluation of amisulpride and escitalopram on Hamilton anxiety rating scale among depression patients in a tertiary care teaching hospital in Nepal. Int J Basic Clin Pharmacol 2015;4:349-53. 